Bot. Soc. Grok. Maxacast, v. 32, n. 2, p. 143-158, 1969 (1971)

\title{
STRATIGRAPHY OF NORTHWESTERN GUATEMALA
}

\section{Russell E. Clemons* and Burke Burkart**}

\section{RESUMEN}

En la parte noroccidental de Guatemala la secuencia sedimentaria es de unos $8,000 \mathrm{~m}$ de espesor, además de las rocas metamórficas y plutónicas de espesor aún desconocido. I as unidades litológicas cartografiadas en el Departamento de Huehuetenango, de la más antigua a la más reciente, son:

1) Las gneises, esquistos, anfibolitas, matepedernal, metacuarcita, metaconglomerado, y rocas metavolcánicas así como meteplutónicas, afloran en el núcleo disectado de los Altos Cuchumatanes y al poniente de Huehuetenango. Las edades de estas rocas no se conocen aún con exactitud, pero éstas subjacen discordantemente a las rocas sedimentarias pensilvánicas.

a) Una secuencia de lutitas apizarradas, limolitas, $y$ una alternancia de lutitas 7 carbonatos, con un espesor aproximado de $1,300 \mathrm{~m}$, ha sido incluida en el Grupo Santa Rosa, de edad pensilvánica (?) - pérmica.

3) Ia secuencia fosilífera, de $500-700 \mathrm{~m}$ de espesor, de caliza $\mathrm{y}$ dolamita con pedernal, gris oscuras, con algunos interestratos de lutita, comprende la Formación Chochal, de edad pérmica.

4) Los intrusivos graníticos, cuya mayoría es más reciente que la Chochal y más antigua que el Jurásico Tardio, afloran en varios de los valles más profundos que cortan a los Altos Cuchumatanes.

5) La Formación Todos Santos de edad jurásica tardia-cretácica temprana, en la parte noroccidental de Guatemala varía en espescr de 5 a 1,250 m. Es, esen. cialmente, una secuencia de capas rojas que consiste en conglomerado, arenisca, limalita, lutita, y en algunas localidades, cerca de su cima, interestratos de caliza gris oscura, hasta de $30 \mathrm{~m}$ de espesor.

6) La Formación Ixcoy de edad cretácica, constituye la unidad más ampliamente distribuida en la parte noroccidental de Guatemala. Consiste en caliza, dolomita, y de algunas unidades de lutita interestratificada con un espesor máximo probable de 2,500-3,000 m.

7) Los intrusivos de serpentina afloran a lo largo de las pendientes meridional y suroccidental de los Altos Cuchumatanes.

8) La Formación Sepur consiste de lutita y arenisca rojas, con caliza inter. estratificada, de unos $250 \mathrm{~m}$ de espesor. Los fósiles de la caliza indican una edad cretácica tardía (campaniana-maestrichtiana).

9) Tobas volcánicas pumíticas, sedimentos tobáceos, y aluvión, constituyen afloramientos aislados principalmente a lo largo de los valles. Depósitos glaciales quedan conservados en un área pequefía a lo largo de la cresta noroccidental de los Altos Cuchumatanes.

* Associate Professor of Geology, Department of Earth Sciences, New Mexico State University, Las Cruces, N. M., U.S.A.

**Associate Professor of Geology, Department of Geology, The University of Texas at Arlington. Arlington, Texas, U.S.A. 


\section{ABSTRACT}

Northwestern Guatemala contains an aggregate sedimentary sequence of approximately $8,000 \mathrm{~m}$ plus an additional, as yet unknown, thickness of metamorphic and plutonic rocks. The rock units mapped in the Departamento Huehuetenango from oldest to youngest are:

1) Gneisses, schists, amphibolites, metachert, metaquartzite, metaconglomerate, metavolcanics, and metaplutonic rocks crop out in the dissected core of the Altos Cuchumatanes and west of Huehuetenango. Ages of these rocks are not known exactly, but they nonconformably underlie sedimentary rocks of Pennsylvanian age.

2) Approximately 1,300 $\mathrm{m}$ of slaty shale, siltstone, and interbedded shale and carbonates have been assigned to the Santa Rosa Group of Pensylvanian (?) Permian age.

4) Granitic intrusives, most of which are probably younger than Chochal and older than Late Jurassic crop out in several of the deeper valleys within the Altos Chuchumatanes.

5) The Todos Santos Formation of Late Jurassic-Early Cretaceous age ranges in thickness from $5-1,250 \mathrm{~m}$ in northwest Guatemala. It is a predominantly red-bed sequence consisting of conglomerate, sandstone, siltstone, and shale with up to $30 \mathrm{~m}$ of dark-gray limestone interbedded near the top at some localities.

6) The Ixcoy Formation of Cretaceous age is the most extensively exposed unit in northwest Guatemala. It is composed of limestone, dolomite, and a few interbedded shale units with a probable maximum thickness of $2,500-3,000 \mathrm{~m}$.

7) Serpentine intrusions crop out along the south and southwest slopes of the Altos Cuchumatanes.

8) The Sepur Formation consists of approximately $250 \mathrm{~m}$ of red shale and sandstone with interbedded limestone. Fossils in the limestone indicate a Late Cretaceous (Campanian-Maestrichtian) age.

9) Pumiceous volcanic tuffs, tuffaceous sediments, and alluvium form scattered exposures, mostly along valleys. Glacial till remains in a small area the northwest crest of the Altos Cuchumatanes.

\section{GENERAL STATEMENT}

Northwestern Guatemala contains perhaps the thickest section of sedimentary rocks in Central America. An aggregate thickness of approximately 8,000 m of sedimentary rocks is exposed in the Altos Cuchumatanes. Relatively good exposures of complete sections in the mountain slopes have motivated earlier workers to name several widespread rock units in these mountains. Yet for most of the units, the relations with adjacent units above and below and areal extensions and variations away from the type section have been uncertain. Mapping at a scale of 1:50,000 has brought out some problems in using all the existing stratigraphic nomenclature that has been proposed in this region. The purpose of this paper is to outline these problerns for consideration by future workers as well as summarizing the results of some recent field studies in northwestern Guatemala. Figure 1 is a generalized index map for the region discussed and Figure 2 shows the generalized stratigraphic section. 


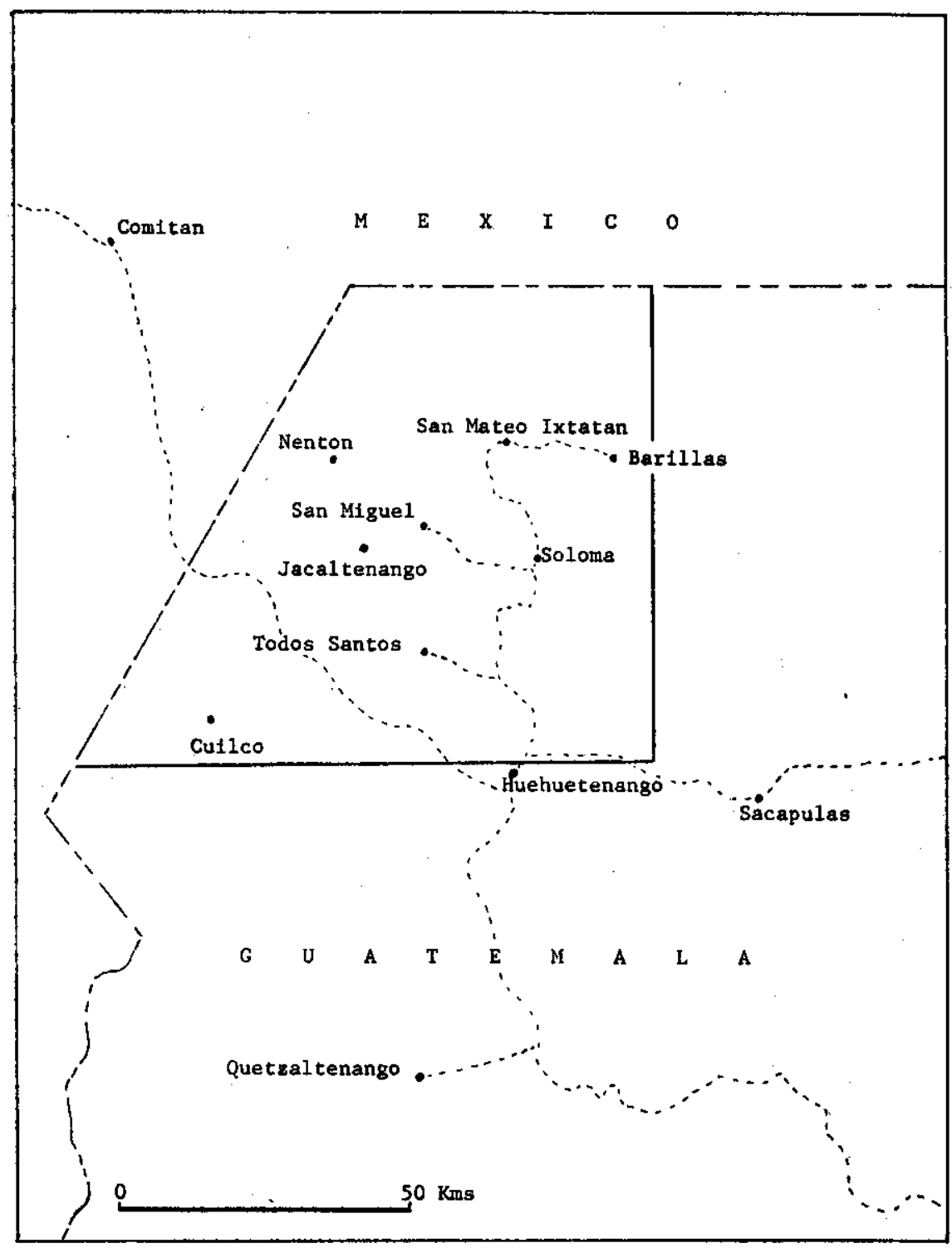

Fro. 1.-Index map of northwestern Guatemala. Area discused is outlined by solid line. 


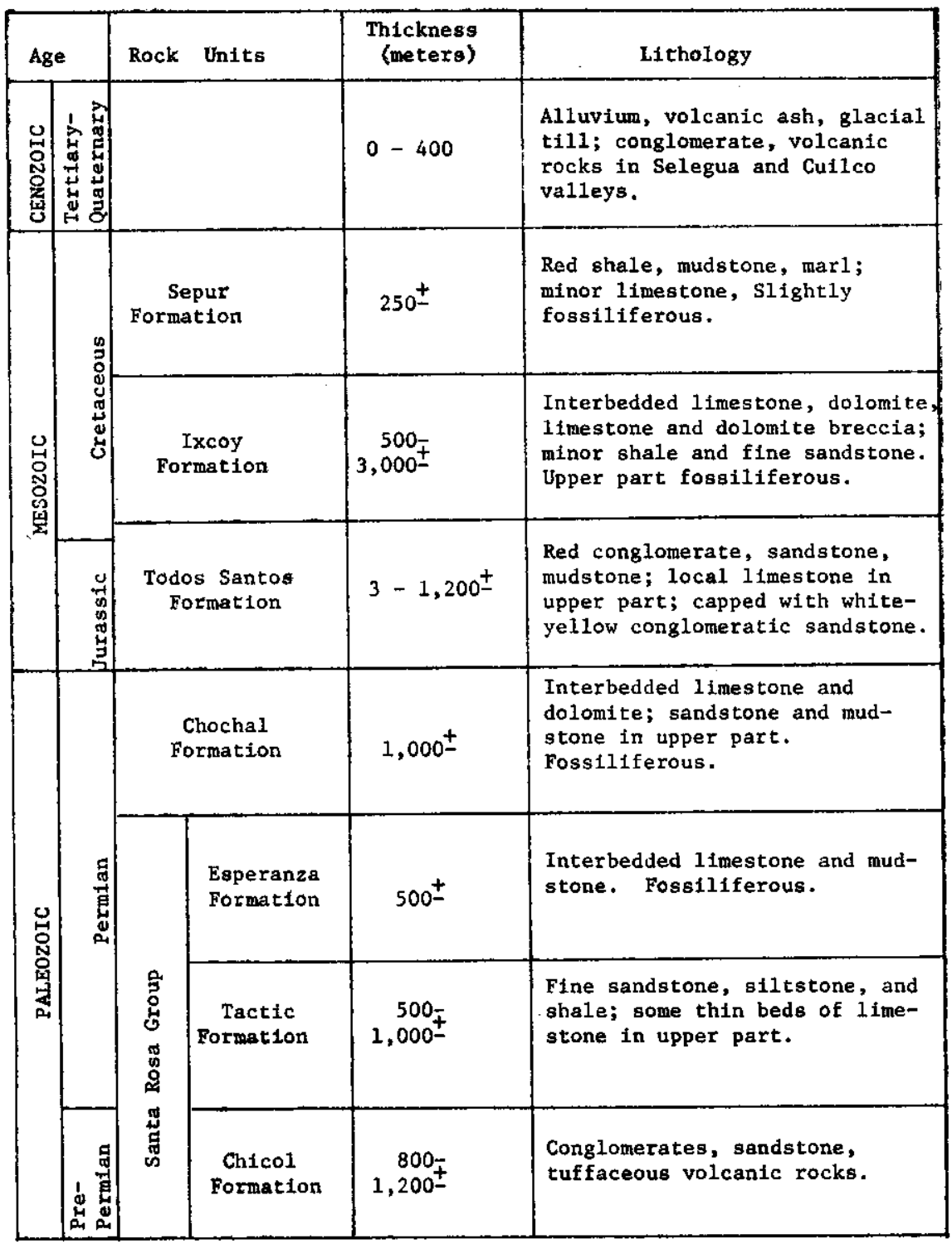

Fic. 2.-Generalized stratigraphic section for northwestern Guatemala. 


\section{BASEMENT COMPLEX}

A wide variety of plutonic and metamorphic rocks underlie the sedimentary sequence in northwestem Guatemala. These basement rocks crop out chiefly in the canyon bottoms of the deeply dissected Altos Cuchumatanes, and in a band adjacent to the southwest flank of the Cuchumatanes and north of the Tertiary-Recent volcanic cover.

Low-grade, regionally metamorphosed sediments comprise the bulk of "basement" exposures within the Altos Cuchumatanes. Sericite and finely crystalline muscovite and biotite provide a sheen on the rock cleavage so that many of these rocks appear to be slates. Thin section study reveals them to have been originally very fine-to fine-grained sandatone.

Locally, chlorite schist, metaquartzite, and metaconglomerate are exposed in some of the canyons. These rocks are probably metamorphosed equivalents of part of the lower Santa Rosa Group.

The grade of metamorphism increases near the plutonic rocks. Gneisses and granite crop out along the Pet, Ixpajua, San Sebastian, and Nubila rivers. Amphibolite crops out near tonalite at Salinas San Miguel. Chiastolite phyllite and schist are exposed near Jacaltenango along the Rio Azul.

Metamorphic and plutonic rocks underlying the sedimentary section in the core of the Altos Cuchumatanes, east of Soloma and Santa Eulalia have been mapped and described by Bohnenberger (1967). The metamorphic rocks are predominantly light-colored, feldspar-biotite gneiss and biotite schist. Amphibolite, metachert, metaquartzite, and metaconglomerate are exposed locally in some of the valleys. These rocks are correlated with similar rocks south and west of Huehuetenango on the basis of lithology and stratigraphic position.

A more detailed study of the metamorphic rocks west of Huehuetenango was done recently by Anderson (1969). He has mapped nather extensive outcrops of blastomylonitic gneiss and schist, biotite gneiss, homblende gneiss, quartz-feldspar-mica gneiss, hornblende-biotite schist, amphibolite, metavolcanic, and metaplutonic rocks. The cataclastic nature of many of these rocks and some similar rocks east of Huehuetenango is due to their position along a major fault zone.

\section{STRATIFIED ROCKS}

Santa Rosa Group.-The name "Santa Rosa" was applied by Dollfus and Montserrat (1868) to rocks exposed near a hamlet of the same name in Baja Verapaz and westward to the vicinity of Huehuetenango. Bohnenberger (oral communication, 1964; 1965) has stated that apparently Dollfus and Montserrat grouped all the sedimentary rocks which they observed into two groups; the lower group (Santa Rosa) included practically all the clastic rocks and limestone interbedded with them, known today as the Santa Rosa shale, part of the Chochal Limestone, and the Todos Santos Formation; the upper group included what today are oalled the Coban Limestone, a part of the Chochal Limestone, and probably the Sepur Shale. Although Dollfus 
and Montserrat found no direct evidence for the age of the Santa Rosa beds, they speculated by a gross lithologic comparison with a similar sequence in Europe, that it might be of Triassic age.

Sapper (1937) applied the name "Santa Rosa" to a sequence of Carboniferous shale and intercalated limestone in central and western Guatemala. The shale sequence, at the original type locality, it has since been demonstrated, is correlative to the Todos Santos Formation of Jurassic age. The name Tactic Formation was substituted for the upper Paleozoic shale sequence (Santa Rosa Formation), which is transitional into overlying Permian limestone, by Walper (1960) in the hope of eliminating confusion that stemmed from having a formation name that applied to rocks throughout northern Guatemala and parts of southern Mexico, but not to the type locality. A few years previously, Roberts and Irving (1957) had defined the overlying Permian rocks (Chocal Limestone) to include "the massive, cliff-forming limestone units that form the upper slopes" above the interbedded limestone and shale units of the middle slopes north of Huehuetenango. Walper defined the upper contact of Tactic Formation "at the base of a 10.foot bed of limestone which is the first bed encountered," and redefined Chochal Limestone to include the interbedded limestone and shale of the middle and lower slopes at the type locality. Thus, neither Walper's Tactic Formation nor Roberts and Irving's Chochal Limestone included interbedded limestone and shale. These beds presented nomenclature problems for recent workers in northwestern Guatemalu.

McBirney (1963) rejected discarding such a well-established name as Santa Rosa. He proposed that Walper's Tactic apply to the uppermost part of the Santa Rosa sequence of Sapper and restrict the name Santa Rosa Formation to the lower coarse clastic unit. Bohnenberger (1965), Burkart (1965), Crane (1965), Clemons (1966), and Bonis (1967) have suggested elevating the name Santa Rosa to group status and retaining Tactic Formation for the upper shale and limestone below the Chochal Limestone of Roberts and Irving. Bohnenberger (1965) also suggested the name Sacapulas Formation for the underlying coarse clastic unit.

Anderson (1969) has objected to retaining the name Santa Rosa. Anderson (1967, 1969), Blount (1967), Boyd (1966), Davis (1966), and Clemons and Burkart (1969) have agreed that the sedimentary rocks underlying the Chochal Limestone of Roberts and Irving (1957) could be subdivided along the southwest front of the Cuchumatanes. Thompson and Miller (1944) subdivided the Pennsylvanian-Permian strata in Chiapas into four formations (in ascending order): Santa Rosa, Grupera, La Vainilla, and Paso Hondo, on the basis of paleontology rather than mappable units. Unable to use this proposed nomenclature, Anderson, Blount, Boyd, and Davis devised the following solutions: Tactic Formation is defined as the sequence of "intensely fractured and folded, predominantly thin-bedded, black shale with some sandstone interbeds, some of which are calcareous." The contacts with the overlying Esperanza Formation which consists of interbedded shale and limestone, is gradationel. The base of the Esperanza is defined as "the first limestone unit greater than five meters thick." The upper contact is defined as "the base of a very prominent scarp-forming, massive carbonate" (Chochal Lime- 
stone of Roberts and Irving). Anderson (1969) also defined a lower coarse clastic sequence the Chicol Formation, a unit probably correlative with the Sacapulas Formation. Clemons and Burkart (1966) proposed to use the name Santa Rosa for the group name which includes three formations: lower Chicol (Sacapulas) Formation, middle Tactic Formation, and upper Esperanza Formation. The name Santa Rosa should be retained because: (1) of its widespread and longstanding use, (2) there is no longer any doubt that Santa Rosa refers to rocks of Pennsylvanian-Permian age, and (3) there is need for a group name to apply to correlative deposits, away from the type localities, and in less well-exposed areas, that cannot or need not be subdivided.

Chicol Formation.-.The Chicol Formation is exposed on both sides of the Chixoy-Polochic Fault where it was mapped by Anderson (1966). About $15 \mathrm{~km}^{2}$ of Chicol Formation is exposed near San Sebastian Huehuetenango. Small deposits mapped by Blount (1967), along the road between Aguacatan and Buenos Aires, as Todos Santos (?) are believed to be Chicol by Anderson (1969). The thickness of the Chicol Formation near San Sebastian Huehuetenango is between 800 and $1200 \mathrm{~m}$. Boulders of Chicol-like débris occur in the valley bottom near Salinas San Miguel. Bohnenberger (1967) mapped rocks that he believed correlated with the Sacapulas Formation in a reconnaissance study of the Soloma and Barillas Quadrangles. Anderson described the Chicol Formation to be conglomerates and breccias with intrusive and volcanic associates. Except for the igneous associates, the lithology is similar to the Sacapulas to the east. Bohnenberger correlates the coarse clastics in the Barillas and Soloma area with the Sacapulas Formation and believes they are also correlative with the Macal Sandstone of Dixon (1956), which is thought to be Late Pennsylvanian in age. The age of the Chicol Formation is not known definitely at present.

Tactic Formation.-The Tactic Formation is the most wide-spread unit of Paleozoic rocks in the northwestern Guatemala. It extends from San Mateo Ixtapan southward to the Chixoy-Polochic Fault, and from the Mexican border eastward to the Coban region. Its maximum thickness in northwestern Guatemala is approximately $1,000 \mathrm{~m}$.

The Tactic Formation is a brown to black sequence of shale, mudstone, and thin siltstone and fine sandstone beds. The shales are phyllitic throughout much of the Cuchumatanes region, and in the deeper valley bottoms slaty shale and metaquartzite are well exposed. Minor amounts of thin limestone interbeds also occur locally in the Tactic.

Several authors have suggested a Pennsylvanian-Permian age for the Tactic rocks. Anderson (1969) argues against a Pennsylvanian age on the fol. lowing basis: (1) no Pennsylvanian fossils have been found in this sequence anywhere in Guatemala, and (2) there is an apparently conformable transitional sequence from Tactic shale into Lower Permian Esperanza shale and carbonate, and then upward into Chochal Limestone.

Esperanza Formation.-The Esperanza Formation is the uppermost unit of the Santa Rosa Group and has only been mapped along the southwestern 
flanks of the Altos Cuchumatanes (Boyd, 1966; Davis, 1966; Anderson, 1967, 1969; Blount, 1967). North of San Miguel Acatan, near the northernmost exposures of the Santa Rosa Group, thin Wolfcampian limestone is interbedded with shale and probably correlative with the Esperanza Formation. More than $470 \mathrm{~m}$ of Esperanza was measured by Anderson (1969) in the San Sebastian Huehuetenango area.

The Esperanza Formation is composed of interbedded fossiliferous shate, sandstone, limestone, and dolomite. The color of fresh shale and carbonate is generally brown to black, weathering to red, brown, yellow, and gray. The Esperanza shale sequence is indistinguishable from the Tactic shales unless fossils are present. The arbitrary criterion for distinguishing between the two is the presence of limestone interbeds, five meters or more in thickness, in the Esperanza Formation. This criterion is not applicable in the northern Cuchumatanes, where limestone beds are thin and scarce in a shale sequence biostratigraphically equivalent to the Esperanza Formation.

Fusulinids of the genus Schwagerina ef. S. campensis Thompson 1954 have been identified by Thomas E. Williams, of Southern Methodist University, from samples taken from the upper part of the Santa Rosa shale sequence near Finca Xoncol. These fusulinids indicate a Wolfcampian age for these rocks.

Chochal Formation.-Roberts and Irving (1957) named the Chochal Formation for the massive Permian carbonates exposed on the southwestern crest of the Altos Chuchumatanes near Huehuetenango. The Chochal Formation is a widespread unit along the southern crest of the Cuchumatanes and in a wide area bounded by the Río Ocho and Río Cuilco. The Chochal also extends eastward to the Coban and Senahu areas (Walper, 1960; Bonis, 1967). The Chochal is mostly missing north of the Rio Ocho fault zone, probably because of a pre-Late Jurassic uplift and erosion. Bohnenberger found several erosional remnants (200 $\mathrm{m}$ or more in thickness) near Barillas. Anderson (1969) stated that there may be as much as $1,000 \mathrm{~m}$ of Chochal in the San Sebastian Huehuetenango area.

The Chochal Formation is a massive-bedded, cliff-forming dolomite and limestone, ranging from light to dark gray in color. It contains highly fossiliferous zones of fusulinids, corals, and brachiopods. Anderson has mapped a shale sequence along the southwestern crest of the Cuchumatanes as the Tuilan Member, which is the youngest part of the Chochal.

Anderson (1969) collected numerous ammonoids, identified by W. M. Furnish and B. F. Glenister of the University of Iowa. Their age was determined as late Leonardian. Kling $(1960)$ believed that the Chochal is somewhat younger in eastern Guatemala with a Leonardian to lower Guadalupian range. Henbest (Robert and Irving, 1957) found the oldest Chochal in northwestern Guatemala to be equivalent to the upper La Vainilla Formation of Mexico, which is younger than Wolfcamp and older than Leonard in age (Thompson and Miller, 1944).

Todos Santos Formation.-The Todos Santos Formation was named by Sapper (1894) for exposures near the village of Todos Santos in the western 
Altos Cuchumatanes. Richards (1963) compared the sections of the Todos Santos in Mexico and Guatemala. He separated the uppermost siltstone, shale, and limestone beds section from the Todos Santos Formation into a newly defined San Ricardo Formation. Two members were designated within the San Ricardo Formation: Ventosa Limestone Member, and Rosario Sandstone Member. The San Ricardo Formation, as defined by Richards, is not a mappable unit in Guatemala. The Todos Santos (sensu stricto) - San Ricardo contact lies within a massive shale unit. The entire red-bed sequence ranges in thickness from more than $1,200 \mathrm{~m}$ to less than $10 \mathrm{~m}$. To date, the Todos Santos Formation has been mapped as originally defined by Sapper, but the Ventosa Limestone Member and Rosario Sandstone Member are mappable units and could be differentiated in slightly larger-scale mapping.

The Todos Santos Formation is exposed in Chiapas, along the southern crest of the Cuchumatanes, and eastward to Baja Verapaz. It is not exposed south of the Chixoy.Polochic Fault in western Guatemala. North of this fault zone, Todos Santos rocks are exposed wherever the Cretaceous carbonates have been removed by uplift and erosion. The northernmost exposures are along the Barillas-San Mateo Ixtatan road and farther west along the southern edge of the Ocante Quadrangle. The thickness ranges of the Todos Santos resulted from having been an exceptionally irregular topography on which was deposited, and which had a northwest-trending grain.

The Todos Santos red-bed sequence consists of conglomerates, sandstone, siltstone, and shale. Thin limestone beds are present locally in the upper part of the sequence. Approximately $450 \mathrm{~m}$ of basal conglomerates have been measured by Richards (1963) and Anderson (1966) near La Ventosa, where the thickest known accumulation of Todos Santos is exposed. About $500 \mathrm{~m}$ of typical flood-plain deposits overlie the conglomerates at La Ventosa. These are overlain in turn by approximately $30 \mathrm{~m}$ of dark gray micritic limestone, $200 \mathrm{~m}$ of red mudstone, oapped by $70 \mathrm{~m}$ of white to yellowish conglomeratic sandstone (Rosario Sandstone Member).

Several distinct facies within the Todos Santos are indicative of local provenance. North of the valley of Rio Cuilco, a thick limestone conglomerate is present near the base of the Todos Santos. The conglomerate contains abundant cobbles bearing fusulinids, brachiopods, and corals, indicating that the conglomerate is reworked Chochal or Esperanza Limestone.

Fusulinid limestone is also present in conglomerate near Jacaltenango. South of the Finca La Reforma Choijl, the Todos Santos is formed of a massive-bedded breccia compnsed of Santa Rosa shales. An arkosic facies is present above the granitic outcrops along the Río San Miguel and Río Catarina, west and north of San Miguel Acatan. The Todos Santos conglomerate near San Marcos Huista contains abundant granitic cobbles and boulders. Metamorphic rock fragments (phyllite, sch lst, and metaquartzite) comprise most of the conglomerate that crops out along the Río Azul below Jacaltenango, Río Limon west of Todos Santos, and Rio San Sebastian east of San Miguel Acatan. The Todos Santos thins to an upper white to yellowish quartzite west of San Miguel Acatan at Gracias a Dios. At this locality the total thickness of the Todos Santos is about $3 \mathrm{~m}$. 
Limestone, resembling the La Ventosa Member, is also present in the canyon north of San Rafael de La Independencia, between San Miguel Acatan and Santa Eulalia. Thicker-bedded, medium-to dark-gray limestone, probably equivalent to the La Ventosa Member, is rather extensive north and northwest of Santa Eulalia.

No new information has been gained on the age of the Todos Santos Formation since Richards' summary (1963), where a Late Jurassic-Early Cretaceous age was assigned. The Todos Santos Formation is correlative with the Continental clastics of the Metapan beds of. Sapper (1899). Richards reported that the Todos Santos is believed to be correlative with the Salinas Formation, a red-bed evaporite sequence of southern Veracruz, Tabasco, and northern Chiapas.

IxcoY Formation.-Carbonate strata of Cretaceous age, which crop out in the Altos Cuchumatanes and Alta Verapaz mountain belt, were named Coban Limestone by Sapper $(1899,1939)$. Termer (1932) was uncertain of the correlation of the carbonates north of Huehuetenango with those to the east near Coban. He applied the name Ixcoy Limestone to the "undifferentiated Cretaceous carbonates" in the Cuchumatanes for the well-exposed section near San Juan Ixcoy. Walper (1960) subdivided the thick Cretaceous section near Coban, retaining the name Coban for the upper (Cenomanian-Turonian) beds and applying Ixcoy to the lower (Neocomian-Albian) beds. Vinson (1967) stated that the Ixcoy Formation "represents an indistinct lower part of the Coban Formation." He subdivided the Cretaceous section into three units: lower Coban Formation of Neocomian to Turonian age, middle Campur Formation of Coniacian to early Campanian age and upper Verapaz Group ' of middle Campanian to late Maestrichtian age.

Lattimore (1962) described a measured section of Cretaceous strata near Chemal in the Cuchumatanes. He applied the name San Cristobal to what Vinson had called the Campur Formation. Recent workers mapping in the region first found only unfossiliferous, brecciated carbonates of Cretaceous age and assigned them to the lithologically similar Coban Formation (Anderson, 1967; Boyd, 1966; Davis, 1966). Blount (1967), Siesser (1967), Bohnenberger (1967), and Anderson (1969) have used the term Ixcoy in the original sense as defined by Termer. No mappable contact has been found within the thick, predominantly carbonate section of the Altos Cuchumatanes. Therefore, the term Ixcoy Formation is preferable. If, at some future date, distinct formations oan be mapped, Ixcoy may be raised to group status as suggested by Bohnenberger (Anderson, 1969).

Distribution and thickness.-The Ixcoy Formation is the most extensively exposed unit in northwestern Guatemala. It forms the crest of the Cuchumatanes, and is exposed continuously off the northwest nose to the lowland along the border with Chiapas. Deep canyons have dissected the Cretaceous section north and west of San Juan Ixcoy, leaving outliers on the ridges. North of San Mateo Ixtatan and Barillas, the surface rocks belong to the Ixcoy Formation, which is exposed continuously down the north flank of the Cuchumatanes into the Peten Lowland.

No complete section has been measured because of the great thickness 
of this unit, the frequency of faulting and folding, extensive karsl development, and heavy vegetation and soil cover. Furthermore, it is not possible to piece measured sections together because of lack of distinctive horizons for correlation. Exposed thicknesses vary from a few meters to a probably maximum of 2,500.3,000 m. Anderson (1967) reported thicknesses in the La Democracia area of 100 to $1,600 \mathrm{~m}$. Anderson (1969) stated that the Ixcoy is probably $500 \mathrm{~m}$ thick in the San Sebastian Huehuetenango area. This thickness is that of erosional remnants where the upper strata have been removed. Blount (1967) estimated the thickness of the Ixcoy to be $1,500 \mathrm{~m}$ in the Chiantla area. If the Ixcoy strata were horizontal at the western end of the Cuchumatanes Plateau, approximately $8 \mathrm{~km}$ north of Todos Santos, a minimum thickness of $1 ; 500 \mathrm{~m}$ is required from the relief on this unit. Accounting for the dip of the strata near the head waters of Río Azul, a thickness of $2,000 \mathrm{~m}$ is estimated and neither the lower nor the upper contacts are exposed. Probably an additional several hundred meters need to be added to both the top and bottom of the section for a maximum thickness of 2,500-3,000 m. A northwest dip of about $8^{\circ}$ was calculated for the Ixcoy strata on the nose of the anticlinorium between Joom and Nenton. Assuming this dip is more or less constant across the $17 \mathrm{~km}$ of lowland to Mexico, a thickness of approximately $2,500 \mathrm{~m}$ is indicated.

The lower contact of the Ixcoy is characteristically poorly exposed due to soil cover and slope wash. The best exposure of the contact is $1.5 \mathrm{~km}$ east of San Miguel Acatan where $5 \mathrm{~m}$ of Ixcoy shale rest disconformably on the Todos Santos conglomeratic sandstone. At many other places the contact can be located within approximately $5 \mathrm{~m}$ because the conglomeratic sandstone forms a resistant ledge, but the nature of this contact has not been determined. The angular unconformity suggested by Lattimore (1962) was not verified by recent studies. The upper contact of the Ixcoy with the overlying Sepur Formation is gradational and conformable as seen in several small stream channels in the Chemal and Tojquia valleys.

Lithology.-Blount (1967) and Anderson (1969) divided the Ixcoy into two facies: (1) a northern facies comprised of foraminiferal limestone, dolomite, and dolomite breccia, and (2) a southern facies which consists of dolomite breccia, shale, sandstone, limestone, lithoclastic limestone, and rudist-lithoclast micrite. These facies are not mappable units throughout northewestern Guatemala.

The base of the Ixcoy, where it was observed, is composed of about $5 \mathrm{~m}$ of shale, grading upward into dark-gray, medium crystalline dolomite, limestone, and dolomite interbedded with massive-bedded limestone breccia. Commonly no bedding is visible in vertical distances of 5 to $10 \mathrm{~m}$. The breccia is clearly a depositional breccia composed of angular pebble-to boulder-size fragments of light-gray limestone, dark-gray limestone, black cherty limestone, gray dolomite, black dolomite, and an ocoasional shale and siltstone clast. The matrix is typically a poorly-sorted calcareous mudstone which weathers to a yellowish-brown. In many places, the breccias are vuggy with partial fillings of sparry calcite. Some of the carbonate: have a strong fetid odor when first broken. A few thin shale beds are also intercalated. 
The middle part of the Ixcoy contains a larger percentage of fine clastic rocks. Near the head of Río Azul, and in the slopes north of Suntelaj, 100 to $150 \mathrm{~m}$ of unfossiliferous, brown, thin-to medium-bedded, friable, porous, calcareous siltstone and very-fine sandstone are predominant with few interbeds of shale and thin-to medium-bedded dark-gray limestone and dolomite. The limestone and dolomite increase in abundance upward in the section for another 100 to $150 \mathrm{~m}$ and the finer crystalline beds are richly fossiliferous with microfossils and algae. There are some tan and dark-gray interbedded argillaceous limestone beds with only sparse microfossils.

The upper Ixcoy consists chiefly of about $1,000 \mathrm{~m}$ of gray-brown and tan, sublithographic, medium-to thick-bedded limestone interbedded with massive intraformational limestone breccia and conglomerate. The limestone contains many zones rich in microfossils, and rudists are abundant at some localities. The breccias and conglomerates contain pebble to boulder-size fragments of dark-gray to black, angular to sub-angular limestone in a matrix of yellowish, calcareous mud. The bedding is indistinct. Breccias and conglomerates decrease in frequency upwards, and light-gray to cream, argil. laceous limestone is interbedded with light - to medium-gray lithographic limestone and thin shale beds. The upper 200 to $300 \mathrm{~m}$, in addition to being distinctly thinner-bedded and smoother-bedded, is also finer textured and contain zones of chert nodules.

The upper contact is fairly 'well defined at Chemal as the highest cherty limestone beds, but the contact is conformable with light-gray clay-stone and marl of the basal Sepur Formation. At Tojquia, the cherty limestone was not observed beneath the Sepur.

From the above general lithologic description it might appear that the Ixcoy could be well divided into three units: lower predominantly massivebedded limestone breccia unit; middle predominantly shale and siltstone unit; and upper limestone breccia, limestone, and shale unit. These have not yet proven to be distinctive maps units, however, and it is usually not possible to state definitely that a particular outcrop belong to one unit rather than another. Folding, faulting, as well as soil and vegetation cover also conceal stratigraphic relations in large areas so that boundary zones cannot be easily traced for any significant distance. A detailed petrographic and stratigraphic study involving much more time might make possible a subdivision of the Ixcoy.

Age and correlation.-The Ixcoy Formation (sensu lato) probably represents most of Cretaceous time. No fossils have been reported from the lower part of the Ixcoy. Richards (1963) presented reasons for considering the upper part of the San Ricardo Formation to be of Late Jurassic-Early Cretaceous age. The Ixcoy, at least locally, can be shown to overlie the San Ricardo unconformably. Therefore, part of Early Cretaceous time is not represented by Ixcoy strata. Parts of the Ixcoy are correlative with the Coban Limestone in the Alta Verapaz region, Sierra Madre Limestone of southern Mexico, and the Yojoa Group (Mills et al., 1967) of Honduras. Vinson (1962) named the upper part of the Ixcoy as the Campur Formation and assigned a Coniacian to Campanian age, on the basis of contained rudistids and micro- 
fossils. Lattimore (1962) called the same rocks San Cristobal and assigned an age of late Campanian or early Maestrichtian on the basis of contained microfauna.

Blount reported on the collected rudistids from the Ixcoy Formation a Turonian-Senonian age. Clemons and Burkart (1969) collected late Campanian to early Maestrichtian (Perkins, 1969, personal communication) rudistids from the top of the Ixcoy. In summary, the upper part of the Ixcoy (sense lato), is correlative in part with the San Cristobal Limestone of Mexico, the Campur Formation of the Coban region, and the lower part of the Valle de Angeles Group (Mills et al., 1967) of Honduras.

Sepur Formation.-The Sepur Formation was defined by Sapper (1899) for a sequence of red-bed clastics, marls, and calcarenites found in northwestern Guatemala and in the southeastern Petén Lowland. Vinson (1962) applied the name Chemal Formation to the red beds of the Alto Cuchumatanes which were mapped by Sapper (1937) as Sepur Formation. It is preferable to retain the name Sepur Formation because there is lithologically, stratigraphically, and chronologically no important difference in these and the widely separated Sepur beds of the type locality in Alta Verapaz. Blount (1967) also mapped these beds as Sepur Formation.

The Sepur Formation overlies Ixcoy Limestone and is preserved in structurally controlled valleys, where it has been downfolded or downfaulted. As a consequence, exposures are small and scarce in the high mountains. The Sepur at Chemal comprises a band about $9 \mathrm{~km}$ long and $1 \mathrm{~km}$ wide. Two smaller exposures are present north of Tojquia. A minimum thickness of $245 \mathrm{~m}$ of a partly-eroded section of Sepur was measured by Blount. Thinbedded limestone and shale, poorly exposed in the lowland along the ChiapasGuatemala border west of Nenton, are probably correlative to the Sepur but are not the typical Sepur lithology.

The Sepur of the Altos Cuchumatanes is primarily a red sandstone and shale sequence with $25 \mathrm{~m}$ of lithoclastic limestone in the upper part of the section. Blount's measured section began in rudistid-bearing, red to orange shale, apparently conformably above the Ixcoy Limestone. In the northwestern part of the Chemal valley, bedding surfaces that are exposed on top of the Ixcoy where the contact should exist, reveal oscillation ripple marks preserved by infillings of chert. The limestone is highly fossiliferous and lithoclastic. Blount classified those in his area as "rudist-lithoclast lime grainstones."

The Sepur was thought to be nearshore marine deposits by Blount on the basis of abundant burrows in the red mudstones of the Chemal valley, as well as the fossiliferous lithoclastic limestone.

Vinson (1962), Lattimore (1962) and Blount (1967) agreed upon a Campanian to Maestrichtian age for the Sepur Formation. It is also correlative to the Lacandon Formation of the Peten Lowland, and the Ocozocuautla Formation of Chiapas.

Quaternary DePosits.-Glacial deposits are present on the high plateau of the Cuchumatanes at elevations between 3,500 and $3,900 \mathrm{~m}$. Anderson 
(1968, 1969) discussed these deposits, attributing them to an ice cap which covered an area of about $50 \mathrm{~km}^{2}$. The deposits are composed of unconsolidated, unsorted, unstratified, limestone débris of sand to boulder size and mud. Solution has removed all evidence of glacial striations within the till as well as along the valley floor and walls. Anderson attributed the extremely flat valley bottoms to glacial scouring.

The till deposits, that are most conspicuos, are draped in a band over two major northwest-trending ridges and two valleys just west of the Llanos de San Miguel. These deposits traversed an area with a relief of over $120 \mathrm{~m}$ and are not related to any important drainage system. At Nimjul a large till deposit, which appears to be a moraine, dams the valley to form a small intermittent lake. Vertical drainage into the karst limestone keeps the lake at a low level.

Enjalbert (1967) first suggested glaciation atop the Cuchumatanes; how. ever, his main argument was based upon interpretations of the Ixcoy Limestone breccias as being a tillite.

Volcanic ash is found in patches in many of the deep river canyons such as at Chanjon near San Martin, and in the Río Chanjon south of San Antonio Huista. A small tuff deposit composed of spherules of devitrified glass, euhedral quartz, K-feldspar, plagioclase, and lithic fragments is present at the northwest end of the Chemal valley. This appears to be an airborne tuff deposit in contrast to those in the river valleys, which are dominantly water deposited.

Alluvium is restricted to the actual river bottoms in the high mountains as there are virtually no flood plains nor Quaternary flood plain deposits. Only where gradients are low and the rivers become confluent in the lowland does extensive alluvium develop. Río Nenton and Río Catarina have such deposits, but even these large rivers become entrenched across the hummocky karst lowland west of Nenton and have very limited flood plains.

An anomalous deposit of thinly scattered gravel, composed of Todos Santos Formation débris, is present in the valley from Tzichim to Zzipen at an elevation of about $3,450 \mathrm{~m}$, high on the limestone plateau just northeast of, and above the village of Todos Santos. The most probable source areas for this detritus are near La Ventosa about $12 \mathrm{~km}$ southeast, at an elevation of $3,400 \mathrm{~m}$. The alluvium may antedate very deep headward erosion of the

- Río Limón which is now interposed between the probable source and the deposit. It is also possible that some glaciofluvial event was responsible for the deposition, but how it might have operated is problematic.

\section{ACKNOWLEDGMENTS}

This paper presents part of the results gathered during two summers of field study in northwestern Guatemala supported by N.S.F. Grant No. GA-853. Suggestions offered by the following geologists, who have consulted with us or been in the field with us in Guatemala, are greatly appreciated: T. H. Anderson, D. N. Blount, Otto Bohnenberger, Gabriel Dengo, S. E. 
Kesler, and W. R. Muehlberger. Field transportation and the facilities of the Instituto Geográfico Nacional de Guatemaka were made available through the generosity of the director, Ing. Manuel Castillo B.. Ings. Jorge Godoy and Oscar Salazar, of the Instituto, expended much time and effort in handling logistics and providing hospitality and innumerable favors which greatly aided the project. We wish to thank all the people in Guatemala whom we met for their hospitality and aid which made it a pleasure working there during the project. We are also grateful to the Sociedad Geológica Mexicana for the opportunity of presenting this paper at the Convención in Oaxaca and its publication.

\section{LITERATURE CITED}

Andenson, T. H., 1967, Geology of the central third of the La Democracia Quadrangle: Texas Univ., Austin, M. A. thesis (unpublished).

- 1968, First evidence for glaciation in Sierra Los Cuchumatanes Range, northwestern Guatemala: Geol. Soc. America, South-Central Mtg., Dellas, Texas, Program and Abstracts, p. 11 (abstract).

- 1969, Geologr of the San Sebastian Huehuenango Quadrangle, Guatemala, Central America: Texas Univ., Austin, Ph. D. dissertation (unpublished).

BLount, D. N., 1967, Geology of the Chiantla Quadrangle, Guatemala: Louisiana State Univ., Baton Rouge," Ph. D. dissertation (unpublished).

BOHNENBEhGRR, O. H., 1965, A propósito de las capas Santa Rose en Guatemala: Primera Reunión de Geólogos de América Central, San José, Costa Rica, Informe, Anexo 3, p. 1.

- 1967 , Geologic reconnaissance of the Soloma and Barillas Quadrangles, Huehuetenango, Guatemala: U. N. Mineral Survey, ICAYT, Guatemala (unpublished).

Bonis, S. B., 1967, Geologic reconnaissance of the Alta Verapaz fold belt, Guatemala: Louisiana State Univ., Baton Rouge, Ph. D. dissertation (unpublished).

Boyd, ALston, 1966, Geology of the western third of La Democracia Quadrangle: Texas Univ., Austin, M. A. thesis (unpublished).

Bunkart, Bunkp, 1965, Geology of the Esquipulas, Chanmagua and Cerro Montecristo Quadrangles, southeastern Guatemala: Rice Univ., Houston, Ph. D. dis. sertation (unpublished).

Curmons, R. E., 1966, Geology of the Chiquimula Quadrangle, Guatemala: Texas Univ., Austin, Ph. D. dissertation (unpublished).

Clrmons, R. E., and Bunkart, Burka, 1969, Geology of the western Altos Cuchumatanes Mountains, northwestern Guatemala: Nat. Sci. Found., Washington, D. C. (unpublished report).

Crane, D. C., 1965, Geology of the Jocotan and Timushan Quadrangles, southeastern Guatemala: Rice Univ., Hnaston, Ph. D. dissertation (unpublished). 
Davis, G. H., 1966, Geology of the eastern third of La Democracia Quadrangle: Texas Univ., Austin, M. A. thesis (unpublished).

Dixon, C. G., 1956, Geology of southern British Honduras: Government Printer: Belice, 85 p.

Dallfus, Auguste, and Montserrat, E. DE, 1868, Voyage géologique dans les Républiques de Guatemala et de Salvador: Miss. Sci. au Mexique et dans l'Amérique Cent., Géologie, Imp. Impériale, Paris 539 p.

EnJalbert, Henri, 1967, Les montagnes calcaires du Mexique et du Guatemala: Annls. Géogr., v. 76, p. 29-59.

Kung, S. A., 1960, Permian fusulinids from Guatemala: Jour. Paleontology, v. 34, p. $637-655$.

LATTimork, R. K., 1962, Two measured sections from the Mesozoic of northwestern Guatemala: Texas Univ., Austin, M. A. thesis (unpublished).

McBrnney, A. R., 1963, Geology of a part of the central Guatemala cordillera: Calif. Univ., Pub. Geol. Sci., v. 38, p. 177-242.

Mriss, R. A., Hugk, K. E., Fenuy, D. E., and Swolfs, H. C., 1967, Mesozoic stratigraphy of Honduras: Bull. Am. Assoc. Petrol. Geologists, v. 51, p. 1711-1786.

RIonakns, H. G., 1963, Stratigraphy of earliest Mesozoic sediments in southeastern Mexico and western Guatemala: Bull. Am. Assoc. Petrol. Geologists, v. 47, p. 1861-1870.

Roberts, R. J., and Inving, E. M., 1957, Mineral deposits of Central America: U. S. Geol. Survey, Bull. 1034, 205 p.

SAPPER, KARL, 1899. Uber Gebirgsbau and Boden des nördlichen Mittelamerika: Petermanns Mitt., Erg-H .127, 119 p.

_._. 1937, Mittelamerika: in Handbuch der regionulen Geologie. Carl Winter, Heidelberg, Bd. 8, Abt 4a, Heft 29, 160 p.

Sizssza, W. G., 1967, Geologr of the Cuilco Quadrangle, Guatemala: Louisiana State Univ., Baton Rouge, M. A. thesis (unpublished).

Trkmer, Frantz, 1932, Geologie von Nordwest-Guatemala: Zeitschr. Gesell. f. Erdkunde, Berlin, p. 240-248.

Trompson, M. L., and MILx.ER, A. K., 1944, The Permian of southernmost Mexico and its fusulinid faunas: Jour. Paleontology, v. 18, p. 481-504.

Vinson, G. L., 1962, Upper Cretaceous and Tertiary stratigraphy of Guatemala: Bull. Am. Assoc. Petrol. Geologists, v. 46, p. 425-456.

Walper, J. L., 1960, Geology of Caban-Purulha area, Alta Verapaz Guatemala: Bull Am. Assoc. Petrol. Geologists, v. 44, p. $1273-1315$. 